\title{
An edaphological, morphological and climatic classification of freshwater forested wetlands from Chile
}

\section{Una clasificación edafológica, morfológica y climática de humedales boscosos de agua dulce de Chile}

\author{
Francisco Correa-Araneda ${ }^{1 *}$, Meyer Guevara-Mora ${ }^{2}$, María Elisa Díaz $^{2}$ \& Ricardo Figueroa ${ }^{2}$ \\ ${ }^{1}$ Departament of Zoology, Faculty of Oceanographic and Natural Sciences, University of Concepción, P.O. Box 160-C, \\ Concepción, Chile. \\ ${ }^{2}$ Water Quality Bioindicators Laboratory, Environmental Sciences Faculty, University of Concepción, P.O. Box 160-C, \\ Concepción, Chile. \\ *E-mail: fjcorrea.araneda@gmail.com
}

\begin{abstract}
Wetlands of the same kind can present considerable difference in relation to a series of environmental variables that influence on the physicochemical properties and on the biological communities sustained, natural variability scarcely considered in comparative studies. The aim of this work was to provide a first approach to the edaphological, morphological and climatic classification of the forested wetlands from central Chile, unique environments for the conservation of an interesting floral and faunal diversity. 18 wetlands were classified in the Araucanía Region, by means of the B classification procedure by the European Union Water Framework Directive. 21 variables at basin scale were used. Four ecotypes were obtained, which were characterized mainly by microclimates and soil types, though were also relevant morphological variables such as slope, slope of the wetlands, and the basins towards they drain (Wilks's Lambda $<0.193, \mathrm{~F}>3.84$ ). Ecotypes determined were defined by: 1) convergence of moderate marine, warm and Mediterranean climates with silty clay loam soil and high slopes, 2) moderate marine climate with silty loam soil and high slopes, 3) Cold Mediterranean climate with silty loam soil and low slopes and 4) Moderate marine climate, silty clay loam soil and high slope. Classification is in agreement with in situ observations. Nevertheless, it must be validated by both limnological and biological approaches.
\end{abstract}

KEYwORDs: Forested wetlands, freshwater, macro-variables, basin, classification, ecotypes, Chile.

\section{RESUMEN}

Humedales del mismo tipo pueden presentar diferencias considerables en relación a una serie de variables ambientales que influyen en las propiedades fisicoquímicas y a su vez en las comunidades biológicas que sustentan. Sin embargo, en estudios comparativos, esta variabilidad natural es generalmente poco considerada. El objetivo de este trabajo fue realizar una primera aproximación de una clasificación edafológica, morfológica y climática de los humedales boscosos de la zona central de Chile, ecosistemas únicos para la conservación de una interesante diversidad de flora y fauna. Se clasificaron 18 humedales presentes en la región de la Araucanía, mediante el procedimiento de clasificación B de la Directiva Marco del Agua de la Unión Europea, utilizando 21 variables a escala de cuenca. Se obtuvieron cuatro ecotipos, caracterizados principalmente por el microclima y tipo de suelo, aunque también fueron relevantes variables morfológicas, como la pendiente y la superficie de sus cuencas (Lambda de Wilks $<0,193, \mathrm{~F}>3,84$ ). Los ecotipos determinados estuvieron definidos por: 1) Convergencia de climas marino fresco, cálido y mediterráneo frio, con suelo franco arcillo limoso y pendientes altas, 2) Clima marino fresco con suelo franco limoso y pendientes altas, 3) Clima mediterráneo frio con suelo franco limosos y pendientes bajas y 4) Clima marino fresco, suelo franco arcillo limoso y pendiente alta. La clasificación debe ser posteriormente validada mediante observaciones in situ de variables limnológicas y biológicas.

Palabras clave: Humedales boscosos, agua dulce, macro-variables, cuenca, clasificación, ecotipos, Chile. 


\section{INTRODUCTION}

Classification of superficial water bodies is a previous and relevant step for all environmental evaluation methods (Resh et al. 1995, Reynoldson et al. 1997). It comes from the necessity of obtaining information about its state and functioning (Bonada et al. 2002, Tiner 2009) in order to carry out proper actions of both conservation and management (Verdonschot \& Nijboer 2004).

Wetland classification systems have been developed in the world for over more than three decades and they correspond mainly to qualitative methods (e.g. Cowardin et al. 1979, Brinson 1993, Warner \& Rubec 1997, Dini et al. 1998, Ramírez et al. 2002, Clausen et al. 2006, Sieben et al. 2016) based on intrinsic characteristics of these water bodies, such as water regime, depth, vegetation and kind of substrate (Adamus et al. 1991, Adamus 1992, Leibowitz et al. 1991, Innis et al. 2000). Despite the development of this kind of classification, diversity of wetlands only has allowed the general grouping of different types of wetlands (e.g. cushion bogs, marsh vegetation or forest; Squeo et al. 2006, Valdovinos 2006, Correa-Araneda et al. 2011) which, in turn can intrinsically present considerable differences because of the edaphological, morphological and climatic variability (Munné \& Prat 1999). In comparative studies, this variability is generally not very considered despite the important influence that macro-spatial variables can have over physicochemical properties of the water (Allan $\&$ Castillo 2007) and on the patterns of the biological communities of these water bodies. A method that diminishes or isolates such variability from the rest of the components, is the delimitation or identification of ecotypes (EC 2000, Marchant et al. 2000, Bonada et al. 2002, Sánchez-Montoya et al. 2007, Traversettti \& Scalici 2014), because this kind of classifications are intended to the identification of reference sites (scarcely perturbed) for every grouping or ecotype, with its inherent biological communities. This would allow establishing real and comparative relations among communities present in the different kinds of wetlands, making easier the determination of its ecological state on the basis of a more reliable and precise way (Gerritsen et al. 2000).

At world-wide level, the greatest advances on this issue have been performed because of the Water Framework Directive (WFD) developed by the European Commission more than fifteen years ago (EC 2000), which presents a number of applications, mainly in Europe (e.g. Bonada et al. 2002; Verdonschot \& Nijboer 2004, Moog et al. 2004, Grindlay et al. 2010, Sánchez-Montoya et al. 2012, Ruiz-García \& Ferreras-Romero 2015). However, reality in Chile shows scarce experience on this issue and at wetland level there are only general classifications adjusted to international models (e.g. Ramírez et al. 2002) and others developed by national agencies encouraged by the frame of the national Strategy for Conservation and Rational Usage of Wetlands (CONAMA 2005), but these are not based on the previously mentioned method. Because of the formerly mentioned, the aim of the current study was delivering a first approach to the edaphological, morphological and climatic classification of ecotypes of forested wetlands, due to their condition of unique environments for the conservation of an interesting floral and faunal diversity in the country.

\section{MATERIAL AND METHODS}

\section{STUdy AREA}

The area under study is located in Southern Chile, specifically in the Araucanía Region $\left(37^{\circ}-40^{\circ} \mathrm{S}\right)$. Preponderant climate in this zone is of wet-Mediterranean type and it is characterized by dry summers and wet winters with annual precipitations in a range of $1200 \mathrm{~mm}$ to 1600 $\mathrm{mm}$. Summer temperatures fluctuate between $14-23^{\circ} \mathrm{C}$ and winter temperatures, between $7-13^{\circ} \mathrm{C}$ (Paskoff 1973, Di Castri \& Hajek 1976, Barry \& Chorley 1985, Luebert \& Pliscoff 2006).

Identification and selection of sampling units was carried out by means of a cartographic predictive model consisting in the superposition of geographic information layers on main attributes respect to the use of soil (flooded meadows, native scrubs) and surface water network (streams and rivers). As potential wetlands those points where all three already mentioned elements converged were considered. Then, they were in situ corroborated, allowing both identification and georeferentiation of 18 sites (Fig. 1). Previously georeferentiated wetlands were delimited by interpretation of aerial photographs (1:20.000) supported by the Chilean Vegetation Census (CONAF-CONAMA-BIRF 2007). Later, a Digital Elevation Model (DEM) based on topographic maps (1:25.000) from the Geographic Military Institute of Chile (IGM 1968) updated to 2000 was used. Thus, delimitation and characterization of the wetlands and their basins was performed (Table 1). All analyses were carried out by means of the software ArcGis 9.3.

VARIABLES USED

Classification of wetlands was carried out by means of the B classification procedure, from the Water Framework Directive by the European Union (EC 2000). In order to achieve this, 21 variables at basin scale were used, grouped in edaphological, morphological and climatic, where those considered as compulsory were included, some optional variables according to such procedure, as well as other added ones, considering the unique features of the kind of ecosystem studied (Table 1, Table 2). 
TABLE 1. Characterization of wetlands studied based on the variables considered for classification. Elev. $=$ Elevation (m.a.s.1.); Slope $\left({ }^{\circ}\right)$; Lat. $=$ Latitude $($ UTM); Long. $=$ Longitude $(\mathrm{UTM}) ; \mathrm{BS}=$ Basin surface $(\mathrm{Ha}) ; \mathrm{WS}=$ Wetland surface $(\mathrm{Ha}) ; \mathrm{BCI}=$ Basin compactness index; Soil texture $(\%)(\mathrm{SL}=\mathrm{Silt}$ loam, FSL = Fine sandy loam, SCL = Silty clay loam, CL $=$ Clay, $\mathrm{REC}=$ Recently $) ; \mathrm{AZ}=$ Agro-climatic zone $(\mathrm{CDL}=$ Coastal Dry Land, $\mathrm{CV}=$ Central Valley $) ; \mathrm{MC}=\mathrm{Micro}-\mathrm{clime} ;(\mathrm{CM}=\mathrm{Cold} \mathrm{Mediterranean}, \mathrm{FM}=\mathrm{Fresh}$ marine, $\mathrm{WM}=$ Warm marine); $\mathrm{AT}=$ Anual Mean Temperature $\left({ }^{\circ} \mathrm{C}\right) ; \mathrm{AP}=$ Annual precipitation $(\mathrm{mm})$.

TABLA 1. Caracterización de los humedales estudiados basada en las variables consideradas para la clasificación. Elev. $=$ Elevación $(\mathrm{m} . \mathrm{s} . n . \mathrm{m}$.$) ; Pendiente \left({ }^{\circ}\right) ;$ Lat. $=$ Latitud $(\mathrm{UTM}) ;$ Long. = Longitud (UTM); BS = Superficie cuenca (Ha); WS = Superficie humedal (Ha); BCI = Índice de compacidad de la cuenca; Textura del suelo (\%) $(\mathrm{SL}=$ Franco limoso, FSL $=$ Franco arenoso fino, $\mathrm{SCL}=$ Franco arcillo limoso, $\mathrm{CL}=$ Arcilloso, $\mathrm{REC}=$ Reciente $) ; \mathrm{AZ}=$ Zona agro-climática $(\mathrm{CDL}=\mathrm{Secano} \mathrm{Costero}, \mathrm{CV}=\mathrm{Valle}$ Central $) ; \mathrm{MC}=\mathrm{Micro}-\mathrm{clima}$

$(\mathrm{CM}=$ Mediterráneo frio, $\mathrm{FM}=$ Marino fresco, $\mathrm{WM}=$ Marino cálido $) ; \mathrm{AT}=$ Temperatura media anual $\left({ }^{\circ} \mathrm{C}\right) ; \mathrm{AP}=\operatorname{Precipitación}$ anual $(\mathrm{mm})$.

\begin{tabular}{|c|c|c|c|c|c|c|c|c|c|c|c|c|c|c|c|c|c|c|}
\hline & Elev. & Slope & Lat. & Long. & BS & WS & $\mathrm{BCI}$ & $\begin{array}{l}\text { BS/ } \\
\text { WS }\end{array}$ & $\mathrm{SL}$ & FSF & SCL & $\mathrm{CL}$ & REC & $\mathrm{AZ}$ & $\mathrm{MC}$ & AT & Isohyet & AP \\
\hline Vergel & 182 & 1.8 & 733692 & 5728936 & 2840 & 138 & 1.6 & 20.6 & 25 & 39 & 36 & 0 & 0 & $\mathrm{CV}$ & $\mathrm{CM}$ & 12.2 & 1600 & 1878.8 \\
\hline Quillem & 239 & 0.8 & 724435 & 5739027 & 3527 & 603 & 1.7 & 5.8 & 0 & 0 & 100 & 0 & 0 & $\mathrm{CV}$ & $\mathrm{CM}$ & 10.5 & 1600 & 1659.9 \\
\hline Pumalal & 158 & 5.9 & 715992 & 5724545 & 3344 & 192 & 1.3 & 17.4 & 0 & 0 & 100 & 0 & 0 & $\mathrm{CV}$ & $\mathrm{CM}$ & 12.2 & 1600 & 1191.4 \\
\hline Quepe & 95 & 0.3 & 706733 & 5694579 & 642 & 346 & 1.5 & 1.9 & 46 & 0 & 54 & 0 & 0 & $\mathrm{CV}$ & $\mathrm{CM}$ & 12.2 & 1600 & 1576.3 \\
\hline Catrimalal & 111 & 2.6 & 706032 & 5714338 & 902 & 587 & 1.2 & 1.5 & 99 & 0 & 0 & 0 & 1 & $\mathrm{CV}$ & $\mathrm{CM}$ & 12.2 & 1600 & 1191.4 \\
\hline Petrenco & 94 & 2.7 & 703296 & 5675733 & 3630 & 269 & 1.2 & 13.5 & 100 & 0 & 0 & 0 & 0 & $\mathrm{CV}$ & FM & 12.2 & 2000 & 1576.3 \\
\hline Pelales & 78 & 0.1 & 697862 & 5694661 & 951 & 161 & 1.3 & 5.9 & 0 & 13 & 87 & 0 & 0 & $\mathrm{CV}$ & $\mathrm{CM}$ & 12.2 & 1600 & 1576.3 \\
\hline Freire & 59 & 0.3 & 696145 & 5686174 & 814 & 65 & 1.7 & 12.5 & 55 & 0 & 0 & 34 & 12 & $\mathrm{CV}$ & $\mathrm{CM}$ & 11.9 & 1600 & 1576.3 \\
\hline Botacura & 70 & 10.2 & 694329 & 5668948 & 4431 & 123 & 1.4 & 36 & 100 & 0 & 0 & 0 & 0 & $\mathrm{CV}$ & FM & 11.7 & 2000 & 2163.3 \\
\hline Botacura B. & 62 & 5.6 & 693414 & 5670662 & 2654 & 247 & 1.2 & 10.7 & 50 & 0 & 50 & 0 & 0 & $\mathrm{CV}$ & FM & 11.7 & 1600 & 2163.3 \\
\hline Labranza & 60 & 0.7 & 692904 & 5707675 & 1434 & 241 & 1.6 & 1.2 & 7 & 0 & 93 & 0 & 0 & $\mathrm{CV}$ & $\mathrm{CM}$ & 12.2 & 1600 & 1191.4 \\
\hline Santa Rosa & 51 & 8.9 & 689305 & 5663514 & 2761 & 202 & 1.2 & 13.7 & 46 & 0 & 54 & 0 & 0 & $\mathrm{CV}$ & FM & 11.7 & 2000 & 2163.3 \\
\hline Los Puentes & 65 & 11.5 & 686512 & 5655648 & 10584 & 331 & 1.4 & 31.9 & 100 & 0 & 0 & 0 & 0 & $\mathrm{CV}$ & FM & 11.7 & 2000 & 2163.3 \\
\hline Mahuidanche & 68 & 10.5 & 684420 & 5662796 & 2195 & 14 & 1.2 & 155.2 & 0 & 0 & 0 & 0 & 100 & $\mathrm{CV}$ & FM & 11.7 & 2000 & 2163.3 \\
\hline Rehuelhue & 36 & 1 & 676257 & 5686245 & 5364 & 1210 & 1.5 & 4.4 & 100 & 0 & 0 & 0 & 0 & $\mathrm{CV}$ & $\mathrm{CM}$ & 11.9 & 1200 & 1255 \\
\hline San Roque & 0 & 11.6 & 676197 & 5660435 & 13487 & 82 & 1.4 & 164 & 100 & 0 & 0 & 0 & 0 & $\mathrm{CDL}$ & FM & 11.9 & 1600 & 1853 \\
\hline Nohualhue & 26 & 7 & 666834 & 5685390 & 2778 & 107 & 1.3 & 26 & 100 & 0 & 0 & 0 & 0 & $\mathrm{CV}$ & $\mathrm{CM}$ & 11.9 & 1200 & 1255 \\
\hline Toltén & -3 & 0.1 & 658293 & 5662739 & 1701 & 62 & 1.4 & 27.5 & 48 & 0 & 52 & 0 & 0 & $\mathrm{CDL}$ & WM & 11.9 & 1600 & 1853 \\
\hline
\end{tabular}




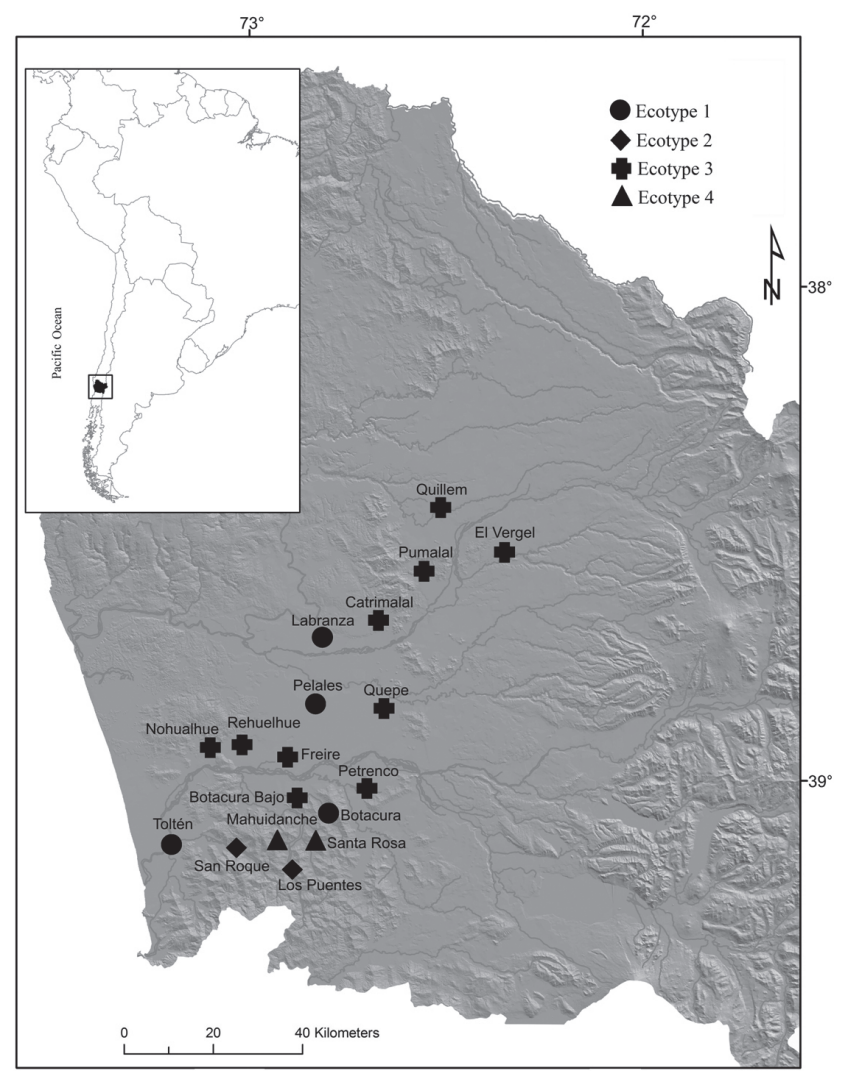

FIGURE 1: Classification of forested wetlands in relation to 4 obtained ecotypes.

Figura 1: Clasificación de humedales boscosos en relación a los 4 ecotipos obtenidos.

\section{Statistical anAlyses}

In order to delimitate the ecotypes, the correlation level among variables previously standardized was determined by means of the Sparman's Statistics Rho, discarding those variables with significant correlations $(\mathrm{r}>0.8 ; p<0.05)$. From these selected variables a principal components analysis (PCA) was carried out and the new axes obtained allowed the application of the K-means non-hierarchical grouping method in order to obtain ecotypes, a priori proving the formation of three to six ecotypes in relation to the maximum differences expected among the selected sites. Later, the Wilks's Lambda discriminant analysis was used to identify the most significant variables $(P<0.05)$ among the ecotypes selected with the K-means statistic, considering the ecotypes that presented values close or equal to zero (different ecotypes), and discarding those ecotypes that presented values close or equal to one (equal ecotypes). However, the selection of a variable does not imply to be considered as discriminant, so the statistic F associated to the Wilks's Lambda distribution was used, and the values of $\mathrm{F}>3.84$ those that were considered as discriminant. Once statistically significant variables were known, the grouping that better explained the sampling sites in the environmental matrix studied was selected.

From the axes obtained of the analyses of the principal components, an Euclidian distance matrix was elaborated, which allowed to perform a parametric multidimensional scaling analysis (NMDS; Clarke \& Green 1988), in order to visualize graphically (three-dimensions) the relation among the previously defined groups. From the very same distance matrix, one way ANOSIM test was carried out (Clarke \& Warwick 2001) in order to determine if such groups statistically differed from each other, using the ecotype as factor. All statistic calculations were performed by jeans of the software SPSS 17.0 (SPSS Inc. Chicago, Illinois) y Primer v.6 (Clarke \& Gorley 2005).

\section{RESULTS}

The wetlands were located mainly in the central valley zone, between -3 (Toltén) and 239 (Quillen) m.a.s.l., with slopes from $0.1^{\circ}$ (Toltén) to $11.6^{\circ}$ (San Roque) and surface between 14.1 (Mahuidanche) y 1209.1 (Rehuelhue) Has. The soil type of the basins was largely silty loam and silty clay loam. The prevailing micro-climes were cold Mediterranean and fresh marine, with temperatures between 10.5 and $12.2^{\circ} \mathrm{C}$ and precipitations between 1255 and 2163.3 (mm year) (Table 1).

After the series of the already determined groupings (3 to 6 groups) was obtained, that one formed by four ecotypes was selected, because it reflected better the spatial patterns of sampling sites. A similar grouping was obtained through the NMDS analysis, where the exploratory analysis indicates the formation of four groups which present highly significant differences (ANOSIM $R$ global $=5.02 ; p=0.004)$ (Fig. 2) Ecotypes were characterized mainly for microclimate and kind of soil, though the slope morphological variable was also relevant (Wilks's Lambda $<0.193 ; \mathrm{F}>3.84$ : Table 3).

Graphic representation of the variables represented as discriminant allowed to characterize every one of the ecotypes (Fig. 3). About this, ecotype 1 formed by four wetlands was characterized by a convergence of climates (marine moderate, warm and Mediterranean cold), with silty clay loam soil and low slopes (0 - $5 \%$ ). Ecotype 2 includes San Roque and Los Puentes wetlands, it has moderate marine climate, with silty loam soil and high slopes (9 $12 \%)$. Ecotype 3 that grouped most of the wetlands (10) has cold Mediterranean climate, with silty loam soil and low slopes. Finally, ecotype 4, with two wetlands (Mahuidanche and Santa Rosa) presented similar features to ecotype 2 and it was characterized by the same climate (marine moderate) and slopes (high), but it was different in the kind of silty clay loam soil (Table 4). 
TABLE 2. List of descriptor variables used for classification of Chilean forested wetlands and its comparison with the variables established for the B Methodology of the Water Framework Directive. A = obligatory variables according to WDF; B = alternative variables according to WFD; $\mathrm{C}=$ new variables included in this classification.

TABLA 2. Listado de variables descriptoras utilizadas para la clasificación de los humedales boscosos de Chile y su comparación con las variables establecidas para la Metodología B de la Directiva Marco del Agua. A = variables obligatorias de acuerdo con WDF; B = variables alternativas según la DMA; C) nuevas variables incluidas en esta clasificación.

\begin{tabular}{|c|c|c|c|c|}
\hline TYPE & Chilean Forested Wetlands & Water Framework Directive & UNIT & \\
\hline \multirow[t]{12}{*}{ Morphologic } & Altitude & Altitude & Meters & A \\
\hline & Slope & Water mean slope & $\%$ & $\mathrm{~B}$ \\
\hline & Latitude & Latitude & UTM & A \\
\hline & Longitude & Longitude & UTM & A \\
\hline & Basin surface & - & Hectares & $\mathrm{C}$ \\
\hline & Wetland surface & - & Hectares & $\mathrm{C}$ \\
\hline & Basin compactness index & Form and configuration of riverbed & - & $\mathrm{B}$ \\
\hline & Basin surface / Wetland surface & - & Hectares & $\mathrm{C}$ \\
\hline & - & Form of the valley & - & $\mathrm{B}$ \\
\hline & - & Water medium deph & Meters & $\mathrm{B}$ \\
\hline & - & Size & Meters & A \\
\hline & - & Distance from river origin & Meters & $\mathrm{B}$ \\
\hline \multirow[t]{2}{*}{ Edaphologic } & Type of soil & - & & $\mathrm{C}$ \\
\hline & - & Substrate mean composition & - & $\mathrm{B}$ \\
\hline \multirow[t]{6}{*}{ Climatic } & Agro-climatic zone, & - & - & $\mathrm{C}$ \\
\hline & Microclimates & - & - & $\mathrm{C}$ \\
\hline & - & Oscillation of air temperatures & ${ }^{\circ} \mathrm{C}$ & B \\
\hline & Temperature & Mean air temperature & ${ }^{\circ} \mathrm{C}$ & B \\
\hline & Precipitations & Precipitations & Millimetres & B \\
\hline & Isohyets & - & Millimetres & $\mathrm{C}$ \\
\hline Geologic & - & Geology & - & A \\
\hline \multirow[t]{6}{*}{ Hydrologic } & - & Flow energy & - & B \\
\hline & - & Mean water depth & Meters & B \\
\hline & - & Flow rate category & $\mathrm{m}^{3} \mathrm{~s}$ & B \\
\hline & - & Solid transportation & - & B \\
\hline & - & Acid neutralization capacity & - & $\mathrm{B}$ \\
\hline & - & Chlorides & $\mathrm{mgL}$ & $\mathrm{B}$ \\
\hline
\end{tabular}

TABLE 3. Discriminant variables according to statistic F associated to the Wilks's Lambda distribution $(\mathrm{F}>3.84)$.

TABLA 3. Variables discriminantes de acuerdo al estadístico F asociado a la distribución de Lambda Wilks.

\begin{tabular}{llccc}
\hline SteP & Variable & Tolerance & F to Remove & Wilks's Lambda \\
\hline 1 & Morphological & 1.00 & 42.25 & - \\
2 & Morphological & 0.89 & 36.31 & 0.45 \\
& Kind of soil & 0.89 & 5.41 & 0.11 \\
3 & Morphological & 0.70 & 28.71 & 0.19 \\
& Kind of soil & 0.80 & 5.53 & 0.06 \\
& Microclimate & 0.64 & 4.64 & 0.05 \\
\hline
\end{tabular}




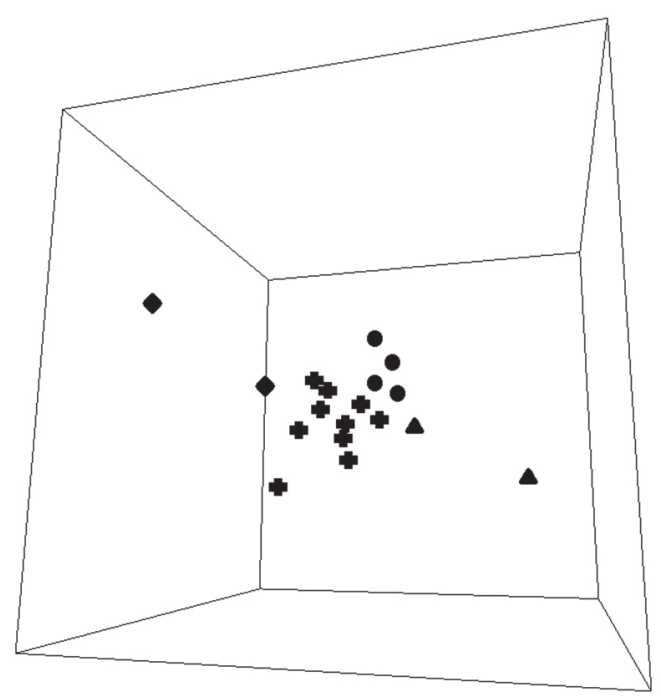

FIGURE 2: Three-dimensional ordering graph of the non-parametric multidimensional scaling (N-MDS), based on axes obtained from the principal component analysis of variables at basin scale. $\bullet=$ Ecotype $1, \bullet=$ Ecotype 2, = Ecotype 3, $\boldsymbol{\Delta}=$ Ecotype 4; stress $3 \mathrm{D}=0.03$.

Figura 2: Gráfico de ordenamiento en 3-dimenciones del escalamiento multidimencional no-paramétrico (N-MDS), basado en los ejes obtenidos del análisis de componentes principales de las variables a escala de cuenca. $\bullet=$ Ecotipo $1, \bullet=$ Ecotipo $2,=$ Ecotipo $3, \boldsymbol{\Delta}=$ Ecotipo 4; estrés $3 \mathrm{D}=0.03$.
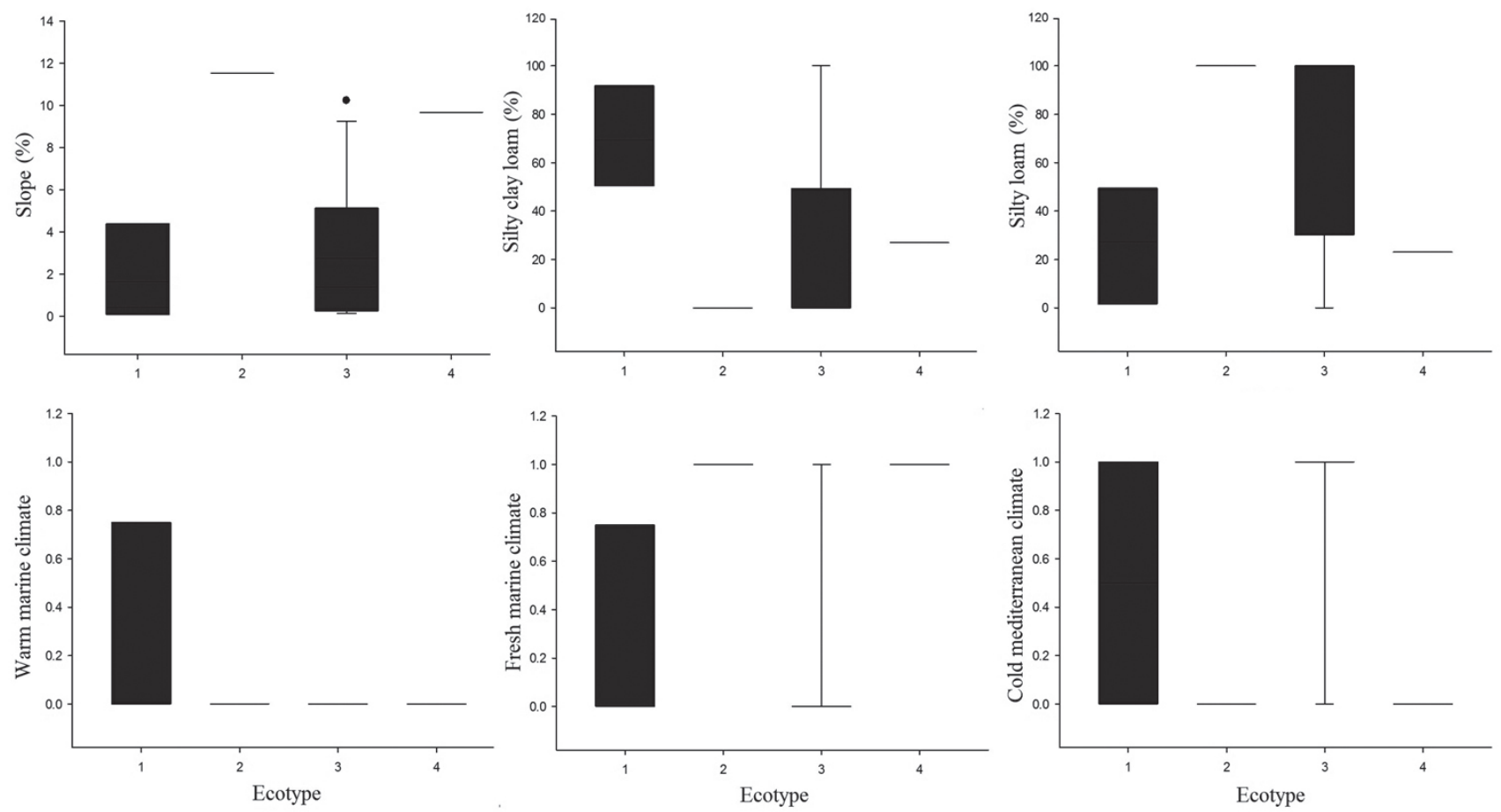

FIGURE 3: Values graph of the variables identified as discriminant for every ecotype.

Figura 3: Gráfico de los valores de las variables identificadas como discriminantes para todos los ecotipos. 
TABLE 4. Ecotype characterization in relation to variables that explain greater differences among them.

TABLA 4. Caracterización de los ecotipos en relación a las variables que explican las mayores diferencias entre ellos.

\begin{tabular}{llll}
\hline & Microclimate & Kind of soil & Slope \\
\hline Ecotype 1 & Fresh, warm marine and cold Mediterranean & Silty clay loam & Low \\
Ecotype 2 & Fresh marine & Silty loam & High \\
Ecotype 3 & Cold Mediterranean & Silty loam & Low \\
Ecotype 4 & Fresh marine & Silty clay loam & High \\
\hline
\end{tabular}

\section{DISCUSSION}

Although the reduction in the natural variability of the aquatic ecosystems by means of the ecotype delimitation method has been recognised as a critical stage and previous to the evaluation of its ecologic state, its applications are recent and confined only to Europe and North America (e.g. Chovarec et al. 2000, Bonada et al. 2002, Verdonschot \& Nijboer 2004, Moog et al. 2004, Dodkins et al. 2005, Grindlay et al. 2010). DMA method for identification of typologies of aquatic ecosystems uses the combination of environmental macro-describers (e.g. geology, climate), though new variables as a function of the local characteristics of water bodies and the availability of information can be added (Verdonschot \& Nijboer 2004). In the current study, new variables such as basin surface, wetland surface, agroclimatic zone were included (Table 2), thus performing an adaptation of the original method to the reality of the studied ecosystem. This is due to the fact that originally such method was conceived for classification of fluvial ecosystems and presents variables measurable only in this kind of system. However, results proved to be a good approach that can be used for the management of these water bodies.

In the zone under study a wet Mediterranean climate predominates, with dry summers and temperatures ranging $14-23{ }^{\circ} \mathrm{C}$ and wet winters, with temperatures between 7-13 ${ }^{\circ} \mathrm{C}$ (Paskoff 1973, Di Castri \& Hajek 1976). At local level, a set of microclimates derived of a high geographic variability is presented through both latitudinal and longitudinal axes. These microclimates prevailed as descriptor variables above macroclimatic variables (temperature and precipitation) and they can be relevant at the time of validating results in relation to environmental variables (physicochemical) and biologic components. At spatial mid-scale, the first parameters of the soil differ from macroclimates given the velocity by which changes are produced affecting, for example, to the drastic variation of the temperature in the first centimetres above the soil (Rosenberg et al. 1983). These are the primary conditioners to the organisms inhabiting the studied ecosystems. On the matter, density of canopy can be a conditioner feature for regulating the variables, over the incidence of outer energy at macroclimate level.
Moderate marine microclimate, determinant to the ecotypes 2 and 4 was characterized by presenting frequent rainfall, with fresh polar air masses that provide abundant clouding and well distributed precipitation, with a maximum in winter (Barry \& Chorley 1985). On the other side, cold Mediterranean climate that defined ecotype 3 presents rainy winters and dry summers which is a consequence of the seasonal variation of the conditions that originate marine climates of the South American western coast. During winter maritime polar air masses predominate along with low pressures and abundant precipitations, whereas during summer maritime tropical air masses predominate, producing important droughts (Barry \& Chorley 1985). This microclimate is similar to the climate that defines the Mediterranean macro-zone (32-41ㅇ S; Di Castri 1981, Strahler \& Strahler 1989), but with lower temperatures both in winter and summer. A relevant aspect to be considered is that ecotype 1 presents a mixture of 3 microclimates which indicates that variables "type of soil" and "slope" are the real descriptor of this grouping. On this matter, the kind of soil was also a relevant factor for the classification of the forested wetlands, by presenting silty loam textures (ecotypes 2 and 3). These were characterized by having a reduced amount of clay (0-25\%), an intermediate amount of fine sand particles (20-50\%), whereas more than half of the particles were silt (70-90 \%) (USDA 2009). This implies a permeability condition and moderate infiltration velocity in a range of $10^{-3}-10 \mathrm{~m} /$ day (Gregory \& Walling 1985, USDA 2009). On the other side, ecotypes 1 and 4 (silty clay loam soil) present a greater clay percentage in their soils (30 40 $\%)$, decreasing their permeability by increasing the clay content (Gavande 1972), causing a decrease in retention and availability of superficial water (Acevedo 2003), as a result of the low infiltration velocity of the soils (Gregory \& Walling 1985, USDA 2009). However, this accumulates in depressions, thus forming the permanent forested wetlands.

In relation to slopes, these presented intermediate values, segregating wetlands in groups of low and high slopes. Thus, ecotypes 1 and 3 are located in flat terrains, whereas 2 and 4 are placed in a moderately inclined relief. The implications of these two kinds of slopes on the wetland features are related mainly on the transport of sediments 
and dragging (Strahler \& Strahler 1989). On the other side, in low zones or flat lands, it is expected that in summer time, when there is a lower water contribution coming from precipitation, a stable availability or water volume is presented (Fuentes-Junco 2004). Therefore, it is possible that most of the wetlands classified as ecotypes 1 and 3, present permanent water regimes, with a decrease in water volume in summer time, though keeping water availability during the whole year, which is in agreement with what was reported by Correa-Araneda et al. (2012, 2014a, b) for the wetlands of Quepe, Petrenco and Nohualhue but not for Pumalal, Catrimalal and El Vergel. This can be associated to the high degree of intervention of their basins, as well as the ecosystem.

The opposite to the case previously described takes place in the zones with higher slopes (ecotypes 2 and 4), where water deficit periods would occur (Fuentes-Junco 2004), because such slopes are characterized by presenting a greater flows and the water resource tends to flow faster out of the basin, favouring the existence of wetlands with shorter water periods (4-8 months; Ramírez et al. 1995) and also influenced by a decrease of precipitations during summer time. Nevertheless, this period can also increase or decrease its duration, in a direct relation with physical characteristics of the basin (Gregory \& Walling 1985, Gavande 1972, Acevedo 2003, USDA 2009. Correa-Araneda et al. 2011).

Even though the present classification agrees in some way with observations carried out in situ, its biological validation becomes fundamental (Sandin \& Johnson 2000, SánchezMontoya et al. 2007), what it is highly complex because the limnological information of these ecosystems is poor and limited to only a few wetlands, especially respect to aquatic communities commonly used for this purpose (e.g. benthic macroinvertebrates). However, recently there have been increased efforts to deepen the knowledge of the aquatic communities of these important ecosystems (e.g. CorreaAraneda et al. 2012, 2014a, b).

Moreover, this lack of knowledge avoids the final calibration of the methods created for the management of water resources. The previous issue is a pending task that it has to be solved by specialists mainly if in recent times several intentions in order to carry out actions intended to the proper management of the Chilean freshwater ecosystems have raised.

Generally, protection of these systems occurs only when there is a legislative support. On this matter, the current Chilean normative only allows regulating the intervention of water bodies by means of the unloading of liquid contaminants, establishing the characteristics of industrial effluents (DS N $^{\circ} 90$ 2000). Despite the fact that this normative is intended to prevent contamination of water bodies by means of controlling contaminants associated to liquid residues, this is not completely effective, because it does not considers the effect that these contaminants can have on the aquatic biota. Before this, and as away to counteract these deficiencies, the elaboration ad implementation of the Secondary Norms of Water Quality is under revision. This norm are initially designed (2004) for large eco-regions and currently with an approach on fluvial or lacustrine basins and with low clarity on wetlands in the planning. Moreover, this norm does not consider the micro-spatial variability, what can lead to errors on water resources management (Abell et al. 2008), what it would happen if ecotype delimitation was considered as an initial stage. This implies the utilization of variables at local level and, therefore, a more accurate classification of the aquatic systems (Gerritsen et al. 2000).

Given the previously stated, it is expected that in later stages of the current study, aquatic communities present in wetlands can be identified. This would be in agreement with the already established ecotypes. At the same time, the degree of intervention of these aquatic ecosystems must be determined, in order to establish possible reference sites for every ecotype and thus, contributing to a more accurate and necessary management of the water bodies.

\section{ACKNOWLEDGMENTS}

This study was financed by CONAF 035-2010 and FONDAP CRHIAM 1513001 projects. Authors would also want to thank Jonathan Urrutia, Marilyn Gonzalez, Pablo Pedreros and María Fernanda Aguayo for their assistance in field work and data analysis.

\section{BIBLIOGRAPHY}

Abell, R., Thieme, M.L. \& Revenga, C. 2008. Moderatewater ecoregions of the world: A new map of biogeographic units for moderatewater biodiversity conservation. BioScience 58: 403-414.

Acevedo, E. 2003. Sustentabilidad en cultivos anuales: Cero labranza, manejo de rastrojos. Facultad de Ciencias Agronómicas, Universidad de Chile, Santiago, Chile. Serie Ciencias Agronómicas No 8.184 pp.

Adamus, P.R. 1992. Wetlands data sources and collection methods. In Statewide wetland strategies: a guide to protecting and managing the resource. World Wildlife Fund, Island Press, Washington, D.C., U.S.A. pp 171-224.

Adamus, P.R., Stockwell, L.T. \& Clairain, E.T. 1991. Wetland Evaluation Technique (WET) Vol. I: Literature Review and Evaluation Rationale. WRP-DE-2. U.S. Army Corps of Engineers Waterways Experiment Station. Vicksburg, MS, U.S.A. 299 pp.

Allan, D.J. \& Castillo, M.M. 2007. Stream Ecology: Structure 
and Function of Running Waters, second ed. Springer, Dordrecht, Netherlands. $450 \mathrm{pp}$.

Barry, R.G. \& Chorley, R.J. 1985. Atmósfera, tiempo y clima. $4^{\circ}$ Edition. Editorial Omega S.A. Barcelona, España. 489 pp.

Bonada, N., Prat, N. \& Munné, A. 2002. Ensayo de una tipología de las cuencas mediterráneas del proyecto GUADALMED siguiendo las directrices de la directiva marco del agua. Limnetica 21:77-98.

BRINSON, M.M. 1993. A hydrogeomorphic classification for wetlands. Wetlands Research Program Technical Report WRP-DE- 4. Final Report, U.S. Army Corps of Engineers Waterways Experiment Station, Vicksburg, MS. 101 pp.

Chovarec, A., Jäger, P. \& Jungwirth, M. 2000. The Austrian way of assessing the ecological integrity of running waters: a contribution to the EU Water Framework Directive. Hydrobiologia 422(423):445-452.

Clarke, K.R. \& Gorley, R.N. 2006. PRIMER v6: User Manual/ Tutorial. PRIMER-E Ltd: Plymouth, UK. 192 pp.

Clarke, K.R. \& Green, R.H. 1988. Statistical design and analysis of a 'biological effects' study. Marine Ecology Progress Series 46:213-226.

Clarke, K.R. \& Warwick, R.M. 2001. Change in Marine Communities: An Approach to Statistical Analysis and Interpretation. Natural Environment Research Council, UK. 172 pp.

Clausen, J.L., Ortega, C. \& Glaude, G. 2006. Classification of wetlands in a Patagonian National Park. Wetlands 26:217229.

Correa-Araneda, F., Gómez-Capponi, F. \& Díaz, M.E. 2014a. Benthic macroinvertebrates community patterns of Mediterranean forested wetlands and their relation with changes in the hydroperiod. Limnetica, 33(2):361-374.

Correa-Araneda, F., De Los Ríos, P. \& Habit E. 2014b. Presence of the red jollytail, Brachygalaxias bullocki (Regan, 1908) (Galaxiformes: Galaxiidae), in freshwater forested wetlands from Chile. Revista Chilena de Historia Natural 87:20-23

Correa-Araneda, F., Urrutia, J. \& Figueroa, R. 2011. Estado del conocimiento y principales amenazas de los humedales boscosos de agua dulce de Chile. Revista Chilena de Historia Natural 84:325-340.

Correa-Araneda, F., Urrutia, J. \& Soto, Y. 2012. Effects of the hydroperiod on the vegetative and community structure of moderatewater forested wetlands, Chile. Journal of Freshwater Ecology 27(3):459-470.

Cowardin, L.M., Carter, V. Golet, F.C. \& Laroe, F.T. 1979. Classification of wetlands and deepwater habitats of the United States. U.S. Department of the Interior, Fish and Wildlife Service Office of biological Services, FWS/OBS79/31103, Washington, DC. 131 pp.

Di CAStri, F. \& HajeK, E. 1976. Bioclimatología de Chile. Editorial Universidad Católica de Chile, Santiago, Chile. 128 pp.

Di CASTRI, F. 1981. Mediterranean-type shrublands of the world. En: Ecosystems of the world 11: Mediterranean-type shrublands. (Eds. Di Castri F., Goodall D.W. \& Specht R.L.) Elsevier, New York, USA. 643 pp.

Dini, J., Cowan, G. \& Goodman, P. 1998. South African national wetland inventory. Proposed wetland classification system for South Africa. South African Wetlands Conservation Program.Pretoria, South Africa. Available via DIALOG. http://www.ngo.grida.no/soesa/nsoer/resource/wetland/ inventory_classif.htm. Cited 8 Aug 2011.

Dodkins, I., Rippey, B.T. \& Harrington, C. 2005. Developing an optimal river typology for biological elements within the Water Framework Directive. Water Research 39:34793486.

DS $\mathrm{N}^{\circ}$ 90. 2000. Norma de emisión para la regulación de contaminantes asociados a las descargas de residuos líquidos a aguas marinas y continentales superficiales. Ministerio Secretaría General de la Presidencia (DO 07.03.2001). $15 \mathrm{pp}$

Environment National Commission (CONAMA). 2005. Estrategia nacional para la conservación y uso racional de los humedales en Chile. CONAMA, Santiago, Chile. 26 pp.

European Commission (EC). 2000. Directive 2000/60/EC of the European parliament of the council of 23 October 2000 establishing a framework for Community action in the field of water policy. Official Journal of the European Communities L327 1-72.

Forest National Corporation - Environment National COMMISSION - INTERNATIONAL BANK OF RECONSTRUCTION AND Promotion (CONAF-CONAMA-BIRF). 2007. Catastro y evaluación de recursos vegetacionales nativos de Chile. Informe Nacional con Variables Ambientales. Santiago, Chile. 88 pp.

Fuentes-Junco, J.J.A. 2004. Análisis morfométrico de cuencas: Caso de estudio del Parque Nacional Pico de Tancítaro. Dirección General de Investigación de Ordenamiento Ecológico y Conservación de Ecosistemas, Instituto Nacional De Ecología, México. 47 pp.

Gavande, S. 1972. Física de suelos principios y aplicaciones. Editorial Limusa, México D.F, México. 351 pp.

Geographic Military Institute of Chile (IGM). 1968. Topographic maps (1:25.000) updated to 2000, Santiago, Chile.

Gerritsen, J., Barbour, M.T. \& King, K. 2000. Apples, oranges and ecoregions: on determining pattern in aquatic assemblages. Journal of the North American Benthological Society 19:487-497.

Gregory, K.J. \& Walling, D.E. 1985. Drainage basin form and process: A geomorphological approach. pp 47-54.

Grindlay, A.L., Zamorano, M. \& Rodríguez, M.I. 2011. Implementation of the European Water Framework Directive: Integration of hydrological and regional planning at the Segura River Basin, southeast Spain. Land Use Policy 28:242-256.

Innis, S.A., Naiman, R.J. \& Elliott, S.R. 2000. Indicators and assessment methods for measuring the ecological integrity of semi-aquatic terrestrial environments. Hydrobiologia 422/423:111-131.

Leibowitz, N.C., SQuires, L. \& BaKeR, J.P. 1991. Research plan for monitoring wetland ecosystems. EPA/600/3-91/010. U.S. Environmental Protection Agency, 588 Environmental Research Laboratory. Corvalis, OR. 168 pp.

Luebert, F. \& Pliscoff, P. 2006. Sinopsis bioclimática y vegetacional de Chile, Santiago de Chile: Editorial Universitaria $316 \mathrm{pp}$.

Marchant, R., Hirst, A. \& Norris, R.H. 1997. Classification and prediction of macroinvertebrate assemblages from running waters in Victoria, Australia. Journal of the North American Benthological Society 16:664-681. 
Moog, O., Schmidt-Kloiber, A. \& Ofenböck, T. 2004. Does the ecoregion approach support the typological demands of the EU Water Framework Directive. Hydrobiologia 516:21-33.

MunNé, A. \& Prat, N. 1999. Regionalización de la cuenca del Ebro para el establecimiento de los objetivos del estado ecológico de sus ríos. Confederación Hidrográfica del Ebro, Zaragoza, Spain. 186 pp.

PAskofF, R.P. 1973. Geomorphological processes and characteristics land-forms in the Mediterranean Regions of the World. In: Mediterranean Type Ecosistems: Origin and structure. (Di Castri, F. \& Mooney, H.A.) Springer-Verlag, New York. 405 pp.

Ramírez, C., San Martín, C. \& Rubilar, H. 2002. Una propuesta para la clasificación de los humedales chilenos. Revista Geográfica de Valparaíso 33:265-273.

Ramírez, C., San Martín, C. \& San Martín, J.1995. Estructura florística de los bosques pantanosos de Chile sur-central. En: Ecología de los bosques nativos de Chile (Armesto, J., Villagrán, C. \& Arroyo, M.K.), pp 215-234. Editorial Universitaria, Santiago, Chile.

Resh, V.H., Norris, R.H. \& Barbour, M.T. 1995. Design and implementation of rapid assessment approaches for water resource monitoring using benthic macroinvertebrates. Australian Journal Ecology 20:108-121.

Reynoldson, T.B., Norris, R.H. \& Resh, V.H. 1997. The reference condition: A comparision of multimetric and multivariate approaches to assess water-quality impairment using benthic macroinvertebrates. Journal of the North American Benthological Society 16:833-852.

Rosenberg, N.J., Blad, B.L. \& Verma, S.B.1983. Microclimate: The biological environment. 2nd edition. J. Wiley, New York. 495 pp.

Ruiz-García, A. \& Ferreras-Romero, M. 2015. Ecological status of headwaters in the wet Betic Mountains (Los Alcornocales Natural Park, southernmost Spain) according to the WFD: Does the application of this Directive ensure conservation? Animal Biodiversity and Conservation 38:59-70.

Sánchez-Montoya, M.D., Arce, M.I. \& Vidal-Abarca, M.R. 2012. Establishing physico-chemical reference conditions in Mediterranean streams according to the European Water Framework Directive. Water Research 46:2257-2269.
Sánchez-Montoya, M.D., Punti, T. \& Suarez, M.L. 2007. Concordance between ecotypes and macroinvertebrate assemblages in Mediterranean streams. Moderatewater Biology 52:2240-2255.

SAndin, L. \& Johnson, R.K. 2000. Ecoregions and benthic macroinvertebrate assemblages of Swedish streams. Journal of the North American Benthological Society 19(3):462-474.

Sieben, E.J.J, Nyambeni, T. \& Mtshali, H. 2016. The herbaceous vegetation of subtropical freshwater wetlands in South Africa: Classification, description and explanatory environmental factors. South African Journal of Botany 104:158-166.

Squeo, F.A., Warner, B.G. \& Aravena, R. 2006. Bofedales: high altitude peatlands of the central Andes. Revista Chilena de Historia Natural 79:245-255.

Strahler, A.N. \& Strahler, A.H. 1989. Geografía física. Tercera Edición Editorial Omega S.A. Barcelona, España. 539 pp.

Tiner, R.W. 2009. Ecology of Wetlands: Classification Systems. Encyclopedia of Inland Waters. pp 516-525.

Traversetti, L. \& Scalici, M. 2014. Assessing the influence of source distance and hydroecoregion on the invertebrate assemblage similarity in central Italy streams. Knowledge and Management of Aquatic Ecosystems 414:02.

USDA. 2009. Soil survey field and laboratory methods manual. Soil Survey Investigations Report No 51, Version1.0. National Soil Survey Center, Natural Resources Conservation Service, Department of Agriculture. Lincoln, Nebraska, USA. 407 pp.

VALDOVINOS, C. 2006. Humedales dulceacuícolas y biodiversidad. En: Atlas social y ambiental del área metropolitana de Concepción. Región del Bío-Bío, Chile (Rojas, J., Azócar G., Muñoz, M.D., Vega, C., Kindler, A. \& Kabisch, S.), pp 104-124. Editorial Universidad de Concepción, Concepción, Chile.

Verdonschot, P.F. \& Nijboer, R.C. 2004. Testing the European stream typology of theWater Framework Directive for macroinvertebrates. Hydrobiologia 516:35-54.

Warner, B.G. \& Rubec, C.D.A. 1997. The Canadian Wetland Classification System. National Wetlands Working Group, Wetlands Research Centre, University of Waterloo, Waterloo, Ontario. Second Edition. 68 pp.

Recibido: 08.04.15

Aceptado: 15.03.16 